ks. Antoni Paciorek

\title{
„Miłujcie waszych nieprzyjaciół” (Mt 5, 3-48)
}

Zawarte w Kazaniu na Górze tzw. antytezy w liczbie pięciu (5, 21-48) osiągają swój szczyt i cel w ostatniej antytezie - przykazaniu miłości nieprzyjaciół. Znaczenie tego przykazania przybliżymy w trzech kolejnych etapach. Najpierw omówimy zagadnienia literackie perykopy (I), następnie przedstawimy znaczenie poszczególnych wypowiedzi (II), wreszcie postaramy się ukazać główne idee teologiczne perykopy.

Pod względem formalnym w tekście piątej antytezy $(5,43-48)$ dominują wypowiedzi podane w trybie rozkazującym. Stanowią obramowanie perykopy. Dwie pierwsze („miłujcie... módlcie się...” - w. 44) przechodzą w obietnicę („będziecie synami...” - w. 45) z następującym uzasadnieniem („ponieważ...”) oraz czterema pytaniami retorycznymi pojawiającymi się w wersetach 46-47. Końcowa wypowiedź, podana - jak wspomniano - w trybie rozkazującym (w. 48) stanowi podsumowanie wywodów zapoczątkowanych w wersecie 43.

Obok imperatywów stanowiących obramowanie perykopy również paralelizm charakteryzuje tę część Kazania na Górze. Jest to paralelizm synonimiczny i antytetyczny pojęć i struktur. Paralelizm pojęć: miłować/modlić się; nieprzyjaciele/prześladowcy; słońce/deszcz, źli/dobrzy; sprawiedliwi/ niesprawiedliwi (45b). Jako paralelizm struktur można wskazać: „Miłujcie waszych nieprzyjaciół / módlcie się za tych, którzy was prześladują...; On sprawia, że słońce wschodzi... / On zsyła deszcz..." (w. 44-45), a także dwa retoryczne pytania: „Jeśli miłujecie tych, którzy was miłują... / Jeśli pozdrawiacie tylko waszych braci..." (ww. 46a. 47a) oraz dwie odpowiedzi: „Czyż i celnicy .../ Czy i poganie...” (ww. 46b. 47b).

Uwzględniając powyższe uwagi strukturę całego fragmentu można przedstawić następująco: 1) Teza: „Będziesz miłował bliźniego, będziesz nienawidził nieprzyjaciela...” - w. 43; 2) Antyteza: „Miłujcie waszych nieprzyjaciół... módlcie się za tych, którzy was prześladują" - w. 44; 3) Uzasadnienie wymogu antytezy: „Tak będziecie synami Ojca w niebie...” w. 45; 4) Dyskusja: „Jeśli miłujecie tych którzy was miłują... Jeśli pozdrawiacie tylko waszych braci... w. 46-47; 5) Konkluzja: „Bądźcie doskonali...” w. 48. 
Łukaszowy materiał paralelny (6, 27-28. 35. 32-34), choć różni się od omawianego tekstu pod względem uporządkowania i słownictwa, pozwala na przypuszczenie, że obydwaj ewangeliści czerpali z $\mathrm{Q}^{1}$. Zestawiając Mt 5, 43nn oraz Łk 6, 27nn dostrzega się znaczne zbieżności nie tyle nawet w słownictwie, ile w treści. Należą do nich przede wszystkim: przykazanie miłości nieprzyjaciół (tutaj podobieństwo dosłowne), wezwanie do modlitwy za prześladowców, obietnica stania się dziećmi Ojca niebieskiego, wskazanie na sposób postępowania Boga (u Łk 6, 35c sformułowana krócej i mniej obrazowo), wskazanie na zachowanie się pogan i celników, wreszcie idea doskonałego i miłosiernego Boga jako wzór do naśladowania. Q jawi się zatem jako baza dla obydwóch ewangelistów. Na tym tle redakcja Mateusza przedstawia się jak następuje:

Jest rzeczą ogólnie przyjętą, że w. 43 jest pochodzenia ewangelisty. Głównym argumentem jest brak u Łk 6, 27nn, a tym samym w Q. Werset 44 jest skróconym przez Mateusza logionem pochodzącym z Łk 6, 27n. Powiązanie przykazania miłości nieprzyjaciół z teologicznym uzasadnieniem (w. 45) pochodzi zapewne z tradycji wcześniejszej, jako że znajduje się u Łk 6, 35. W ogóle werset 45 u Mateusza odznacza się większą obrazowością, niż paralelna wypowiedź u Łk. Można zatem uznać go za bardziej pierwotny. W wypadku ww. 46-47 trudno ustalić czy tekst Mateusza czy paralelny Łukasza jest bardziej pierwotny. Sprowadzenie do dwóch tylko członów, czyli skrócenie wypowiedzi pochodzi zapewne od Mateusza. W ten sposób chciał on zachować proporcje w przedkładaniu antytez. Od Łukasza pochodzą zapewne uogólnienia („grzesznik” zamiast „celnik/poganin”; „czynić dobrze” zamiast „pozdrawiać”). Trudno rozstrzygnąć, czy bardziej pierwotna jest u Mt „zapłata”, czy też wyrażenie Łukaszowe: „łaska”. Na ogół przyjmuje się, że „łaska” jest Łukaszowym słowem². Ale z kolei także „zapłata” jest słowem ważnym w słownictwie Mateusza. Wreszcie w. 5, 48 odpowiada Łk 6, 36 z tym jednak, że Łk mówi o Ojcu „miłosiernym”: „Bądźcie miłosierni, jak Ojciec wasz niebieski jest miłosierny”. Określenie „miłosierny” jest charakterystyczne dla Łukasza.

Pierwsza część starotestamentalnej tezy: „Będziesz miłował bliźniego swego" (43b) pochodzi z Kpł 19, 18b (dosłownie wg LXX, dlatego miara

${ }^{1}$ Zob. U. LuZ, Das Evangelium nach Matthäus, EKK NT, Zürich I/1, 1985, s. 306; Natomiast D. A. Hagner (Matthew 1-13, WBC 33A, Dallas, Texas 1993, s. 133) jakkolwiek dopuszcza możliwość pochodzenia tekstu od tego samego źródła Q to jednak bardziej prawdopodobna jest zależność Mateusza i Łukasza od różnych źródeł obejmujących materiał pochodzący od Jezusa. Zob. także W. D. Davies, D. C. Allison, The Gospel according to Matthew, I, Edinbourgh 1988, s. 504n.

${ }^{2}$ Zob. J. GnILKA, Das Matthäusevangelium, I, HTKNT I-1, Freiburg: Herder 1986, 189. Zastrzeżenia zob. Luz, Matthäusevangelium, s. 306. 
miłości: „jak siebie samego” nie została podana). „Miłować” w tym starotestamentalnym fragmencie Kpł $(19,11-18 a)$ oznacza powstrzymywać się od czynienia jakiegokolwiek zła. Jeśli jednak weźmiemy pod uwagę zbliżone treściowo teksty z Pwt 10, 18-19 i Kpł 19, 33-34, dostrzegamy, że czasownik „miłować” posiada także znaczenie pozytywnego działania. W konsekwencji należy stwierdzić, że wg ST miłować bliźniego oznacza nie tylko powstrzymać się od wyrządzania mu krzywdy, ale oznacza także pozytywnie działać dla jego dobra. Owym bliźnim jest jednak członek narodu izraelskiego ${ }^{3}$. A w każdym razie nie jest bliźnim nieprzyjaciel narodu. ST dopuszcza zatem niemiłowanie nieprzyjaciela. Tym niemniej, druga część podanej przez ewangelistę tezy: „a nieprzyjaciela swego będziesz nienawidził" (43c), nie pojawia się w żadnym miejscu ST. Powstaje pytanie, skąd ewangelista zaczerpnął drugą część starotestamentalnej tezy.

Jest możliwe, że owa druga część tezy stanowi niejako wniosek wyprowadzony z części pierwszej, jest jej komentarzem i oznacza po prostu: „ale nie jesteś

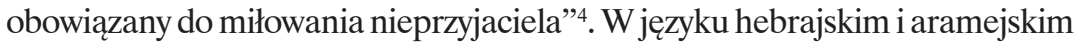
czasownik „nienawidzić” może mieć znaczenie po prostu braku miłości (np. Pwt 21, 15). W takim wypadku antyteza Jezusowa nakazywałaby miłowanie nieprzyjaciół, do czego w sposób pozytywny ST nie zobowiązywał.

O tym, że tak właśnie mogło być rozumiane starotestamentalne przykazanie miłowania bliźniego, wskazywałby nakaz nienawiści nieprzyjaciół spotykany w Qumran. Znajdujemy tam zalecenie miłowania wszystkich synów światłości i nienawidzenia wszystkich synów ciemności (1QS 1, 9n). Nieprzyjacielem i synem ciemności jest każdy, kto nie należy do wspólnoty synów światłości, czyli do społeczności qumrańskiej, nawet Żyd, jeśli pozostaje poza jej obrębem. Takie stanowisko może stanowić także echo tzw. świętej nienawiści wyrażanej w niektórych psalmach (por. Ps 25, 51 LXX: „Znienawidziłem czyniących nieprawość, i z bezbożnymi nie zasiądę...” 100, 3 LXX; a zwłaszcza 138, 21-22 LXX: „Czyż nie znienawidziłem nienawidzących Ciebie, Panie? (...). Nienawidzę ich aż do końca, stali się moimi wrogami”). Można zatem przypuszczać, że idea nienawiści nieprzyjaciół zaznaczona w specyficznym kontekście wymienionych psalmów wyraziła się wyraźnie w nurcie qumrańskim i znana była w judaizmie. Mateusz przywołał na pamięć owo bardziej lub mniej świadomie wyrażane w judaizmie przekonanie, ponieważ nie mógł sformułować antytezy wychodząc wyłącznie z przykazania miłowania bliźniego (trudno byłoby wówczas wyrazić owo „więcej” w nauce

\footnotetext{
${ }^{3}$ Por. Bill. I, 354.

${ }^{4}$ Taki sposób rozumienia sugeruje np. Biblia Jerozolimska (wyd. fr. z r. 1973). Por. M. DuMAIs, Il Discorso della Montagna. Storia della ricerca, Torino: ELLEDICI 1999, s. 272.
} 
Jezusa i chrześcijaństwie). Z tego powodu przytoczył przykazanie miłości bliźniego przekazywane w środowisku judaistycznym wraz z jego interpretacją, która wyraźnie wyklucza nieprzyjaciół z obszaru miłości ${ }^{5}$.

Antytezą jest przykazanie miłości nieprzyjaciół: „A Ja wam powiadam: Miłujcie waszych nieprzyjaciół i módlcie się za tych, którzy was prześladują” (w. 44). Z kontekstu wynika, że nieprzyjaciółmi są przede wszystkim prześladowcy chrześcijan. W Ewangelii Mateusza podobnie jak w NT w ogóle słowa: „prześladowca, prześladować” były terminami technicznymi dla określenia prześladowań, którym poddani byli chrześcijanie z powodu swej wierności Chrystusowi (por. Mt 5, 10-12; 10, 23; 13, 21; 23, 34). Wśród owych prześladowców znajdowali się najpierw Żydzi, ale także świat pogański (por. Mt 10, 22; 24, 9). Tak więc na pierwszym planie wśród nieprzyjaciół znajduje się „nieprzyjaciel wierzących”. Z drugiej jednak strony przykazanie miłości nieprzyjaciół odnosi się także do osobistych wrogów. Wynika to z wskazania, aby nie miłować jedynie tych, co nas miłują (ww. 46-47)6. Miłość chrześcijanina powinna rozciągać się także na tych wszystkich, którzy nie miłują go i osobiście występują przeciwko niemu.

Miłość o której tu jest mowa, nie jest sprawą emocji i sentymentu, ale polega na postawie życzliwości wyrażającej się w konkretnych czynach. Owe czyny to: modlitwa za prześladowców (w. 44b), pozdrawianie tych, którzy nie są naszymi braćmi (w. 47), czyli życzenie im pokoju i dóbr mesjańskich obiecanych przez Boga (w Łukaszowym miejscu paralelnym przykazanie miłości bliźniego uściślone jest trzema szczegółowymi zaleceniami: „czyńcie dobrze”, „błogosławcie”, „módlcie się”). W Jezusowym nakazie miłości idzie zatem o życzliwość aktywną.

Trzeba przyznać, że ST zawiera pewne wypowiedzi zachęcające do okazania pomocy nieprzyjaciołom w szczególnych sytuacjach (Wj 23, 45; Prz 25, 21). Zachęty te zostały przejęte przez literaturę rabinistyczną, jakkolwiek nigdy nie mówi się tam o miłowaniu nieprzyjaciół․ Ponadto, zachęty do okazywania pomocy nieprzyjaciołom mają jednak na uwadze jedynie Izraelitę, który akurat stał się wrogiem dla drugiego Izraelity, podczas kiedy Jezus mówi o miłości względem nieprzyjaciół narodu ${ }^{8}$. Także w hellenizmie, zwłaszcza w filozofii stoickiej spotykamy się z wezwaniem miłowania wszystkich ludzi ${ }^{9}$. Tutaj jednak jako motyw takiego działania

${ }^{5}$ Dumais, Discorso, s. 272n; por. także Luz, Matthäusevangelium, I, s. 311.

${ }^{6}$ Istnieją autorzy (S. Legasse, Et qui est mon prochain?, Cerf: Paris 1989, 103-108), którzy utrzymują, że w perspektywie antytezy nie pojawiają się nieprzyjaciele osobiści. Bardziej przyjmowana jest opinia przeciwna.

${ }^{7}$ Mek Ex 23, 4; por. Bill. I, 368-369.

${ }^{8}$ Legasse, Mon prochain, 78-92. 
podane jest poszanowanie natury, którą nienawiść degraduje i niszczy. Miłość nieprzyjaciół nie była zatem w stoicyzmie czymś nadzwyczajnym ale była rozumiana jako rzecz zupełnie naturalna. Teksty stoickie pozornie zbliżone do ewangelii oddalają się jednak znacznie od nauczania Jezusa, który uważa, że naturalną skłonnością człowieka jest miłować jedynie tych, którzy go miłują (w. 46), i który ustanawia przykazanie miłości nieprzyjaciół jako naśladowanie postępowania Boga osobowego.

Tak więc przykazanie miłości tak jak jest ono sformułowane w Mt 5, 4344 (i Łk 6, 27.35) jest niesprowadzalne do jakiegokolwiek nurtu ideowego. Nigdy, przed Jezusem przykazanie to nie zostało wyrażone w sposób tak radykalny i absolutny. Przykazanie miłości nieprzyjaciół stanowi charakterystyczną i wyłączną własność Jezusa. Jest ono bezwarunkowe i nie ma na celu „nawrócenie” nieprzyjaciela. Jezusowe wezwanie do miłości nieprzyjaciół odzwierciedla się w wielu innych nowotestamentalnych pismach (np. Łk 23, 34; Dz 7, 60; Rz 12, 14. 17-20; 1 Kor 4, 12-13; 1 Tes 5, 15; 1 P 3, 9), a także we wczesnych pismach chrześcijańskich (Polikarp, 12, 3; Iren. Adv. haer. 3, 18, 5; 2 Klem 13, 4; Justyn I Apol 14, 3 i in.).

Wezwanie do miłości nieprzyjaciół jest nie tylko zasadą moralną, ale jeśli jest zaakceptowane i wypełnione przez człowieka, buduje pomiędzy człowiekiem a Bogiem relację Ojciec - syn: „Tak będziecie synami Ojca waszego, który jest w niebie" (w. 45a). W momencie kiedy uznajemy, że wszyscy są dziećmi jednego Boga, stajemy po stronie Ojca. Ktokolwiek więc jest w stanie miłować nieprzyjaciół, okazuje się dzieckiem Bożym: „Bądźcie naśladowcami Boga jak umiłowane dzieci i postępujcie w miłości..." (Ef 5, 1-2; por. także $1 \mathrm{~J} 4,7-12 ; 1 \mathrm{P}$ 1, 13-25). Po podobieństwie poznaje się pokrewieństwo. Otóż Bóg swoimi dobrodziejstwami obdarza wszystkich ludzi, dobrych i złych, sprawiedliwych i niesprawiedliwych: „On sprawia, że słońce Jego wschodzi nad złymi i dobrymi, i On zsyła deszcz na sprawiedliwych i niesprawiedliwych" (w. 45bc). Spośród dobrodziejstw przykładowo wymienione zostają konkretnie dwa czynniki niezbędne do życia: słońce i deszcz. Wnioskowanie idzie tu od świata przyrody zmierzając do ukazania natury Boga. Bóg jest bowiem stwórcą zarówno świata przyrody i świata duchowego. Zatem pomiędzy obydwoma powinna istnieć odpowiedniość (por. Ps 19; Rz 1, 19; 1 Kor 11, 13-16). Bóg, który zsyła deszcz na sprawiedliwych i niesprawiedliwych, miłuje jednych jak i drugich.

Powstaje pytanie, jak rozumieć należy owo dziecięctwo Boże? Czy jest ono nagrodą za należyte postępowanie i objawi się w przyszłości, czy też

${ }^{9}$ Mar. Aur. Semet. 7, 21: „Także tych miłować, którzy wobec nas zawinili, stanowi szczególny obowiązek człowieka”. Inne przykłady z Epikteta i Seneki zob. LEGASSE, Mon prochain, 96. 
jest ono naturą człowieka, która powinna się objawić poprzez naśladowanie Boga. Za rozumieniem pierwszym przemawia fakt, że uczniowie, którzy już teraz mogą nazywać Boga Ojcem, powinni pełnić dzieła swego Ojca (5, 16). Za drugim przemawia to, że w 7 błogosławieństwie, gdzie dziecięctwo Boże ukazane jest jako eschatologiczna nagroda $(5,9)$. Wydaje się, że należy to rozumieć w sensie dynamicznym. Bóg już teraz przyjął uczniów jako swoich synów. Jak długo jednak żyją oni na świecie, pozostają zawsze w sytuacji próby, dlatego nie są ostatecznie i nieodwołalnie dziećmi Bożymi. Dopiero przy końcu staną się takimi.

Dwa następujące logia uzmysławiają (ww. 46-47), że miłość nieprzyjaciół nie usuwa w cień ani nie wyklucza miłości przyjaciół. Tych należy oczywiście pozdrawiać (w. 47). Ale to nic szczególnego. Także ci, którzy znajdują się zupełnie nisko na skali szacunku religijnego i społecznego (celnicy i poganie) umieją pozdrawiać siebie wzajemnie i wyświadczać sobie przysługi. Dopiero

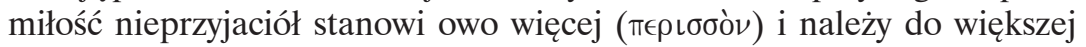
sprawiedliwości $(5,20)$ przeciwstawiając się „normalnemu” zachowaniu ludzi. To ostatnie jest uformowane poprzez egoistyczną kalkulację: miłować/ pozdrawiać tylko tych, którzy nas miłują/pozdrawiają. Przedstawicielami takiego rozumowania są celnicy i poganie (por. 18, 17). Celnicy i poganie pojawiają się tutaj w charakterystycznym dla judaizmu negatywnym świetle (Łukasz zastępuje powyższe określenia słowem: ,grzesznicy”). Pozdrowienie, które jest wyrazem otwarcia i życzliwości ma być kierowane nie tylko ku braciom, czyli należącym do wspólnoty kościelnej. Etyka chrześcijańska przeciwstawia się utylitarystycznej i kalkulującej etyce. Uczeń Jezusa wezwany jest do miłowania nieprzyjaciół nie spodziewając się niczego w zamian. Mt 5, 6-47 (oraz paralelny tekst Łk 6, 32-35) ukazują, że przykazanie miłości nieprzyjaciół nie należy do obszaru zwyczajności i pewnej naturalności. Mateusz przypomina to przykazanie wspólnocie, nie dlatego, że zgadza się ono ze zdrowym rozsądkiem, ale dlatego, że przekazuje je zmartwychwstały Chrystus, który żyje i działa we wspólnocie aż do skończenia świata (28, 20). Problem zatem tkwi nie w tym, czy przykazanie to jest psychologicznie realistyczne, ale czy nasze doświadczenie łaski Boga, którą ono zakłada, jest wystarczająco silne, aby osoba ludzka mogła żyć miłością, która nie jest pochodzenia ludzkiego lecz Bożego.

Ostatni werset perykopy zawierający wezwanie do doskonałości („Bądźcie więc wy doskonali, jak doskonały jest Ojciec wasz niebieski” - w. 48) znajduje swój odpowiednik u Łk 6, 36 czyli w Q: „Bądźcie miłosierni, jak Ojciec wasz jest miłosierny". Wzorem dla takiego sformułowania w. 48 jest najwyraźniej Kpł 19, 2: „Świętymi bądźcie, bo Ja jestem święty, Jahwe, wasz Bóg”. Mateusz wprowadził zatem określenie: „doskonały” w odniesieniu do 
Boga i zobowiązał uczniów Jezusa do naśladowania tej doskonałości. Powstaje zatem pytanie, co oznacza określenie „doskonały”? W judaistycznych tekstach człowiek może być nazwany doskonały z powodu swej pobożności oraz posłuszeństwa. Takimi byli np. Noe i Abraham. Do doskonałości należą dwa elementy: niepodzielność serca i pełne posłuszeństwo jako subiektywny element oraz całkowite wypełnianie przykazań Prawa jako element obiektywny. Doskonały jest ten, kto wypełnia wszystkie nakazy Boga. Doskonałość zatem w rozumieniu Mateusza to niepodzielne przyjęcie głoszonego przez Jezusa orędzia. Z drugiej jednak strony, należy zauważyć, że miarą doskonałości jest sam Bóg. ST nie mówi o Bogu doskonałym ${ }^{10}$. Tymczasem w omawianym miejscu Bóg nazwany jest doskonałym i ukazany jako wzorzec do naśladowania. Na czym więc polega doskonałość Boga? Biorąc pod uwagę etymologiczne

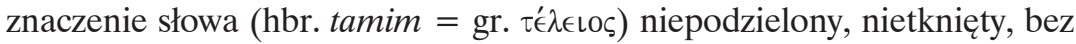
skazy - określenie przynosi wyobrażenie czegoś nie podzielonego, całkowitego, pełnego. Bóg jest doskonały, ponieważ w swej dobroci zwrócony jest całkowicie ku człowiekowi. Jest doskonały obdarzając ,sprawiedliwych i niesprawiedliwych” swymi dobrodziejstwami. Dlatego też jest „Ojcem niebieskim”. Doskonałość człowieka polegałaby zatem na niewzruszonej miłości, która żadnego człowieka nie wyklucza. Jest rzeczą oczywistą, że ludzie nie osiągną miary Bożej doskonałości. W ograniczonej jednak mierze człowiek w swojej miłości może i powinien odznaczać się niepodzielnością czyli na swój sposób pełnią. Konkretnie. Jeśli więc Mateusz zmienił brzmienie Q, jakkolwiek i jemu szło ostatecznie o dobroć i miłosierdzie Boga, to dlatego, aby podkreślić znaczenie przykazania miłości nieprzyjaciół. Miłość nieprzyjaciół nie jest jednym z wielu wskazań, ale szczytem i ośrodkiem przykazań prowadzących do doskonałości.

1) Realizm zobowiązań Jezusowych $(5,21-48)$. Nierzadko spotyka się stwierdzenia, jakoby ukazany przez Jezusa ideał nie był do zrealizowania przez człowieka. Istotnie, 5, 21-48 zawiera przykazania, których dosłowne zachowywanie może prowadzić do sytuacji beznadziejnie skomplikowanych. Trzeba tu jednak mieć na uwadze czego właściwie dotyczy cały ten fragment? Otóż nie jest on zbiorem przepisów prawnych (z wyjątkiem 5, 32), ale zawiera ogólny kierunek postępowania dla tych, którzy są uczniami Chrystusa. W tej wizji nowej moralności prawo ST zachowuje swą ważność. Nie zostaje usunięte ani zastąpione przez nowe prawodawstwo. To co pojawia się nowego, to nowe nastawienie, nowy duch, nowa wizja. To $\mathrm{z}$ tego powodu 5, 21-48 jest tak obrazowe, tak poetyckie i dramatyczne.

${ }^{10}$ L. SABourin, Why is God Called 'Perfect' in Mt 5, 48?, BZ NF 24 (1980), 266 wskazuje na Sdz 9, 5; 2 Krl 15, 32; Hi 37, 16; Ps 18, 31. 
Z tego też powodu dosłowna interpretacja wypowiedzi jako wypowiedzi prawnych może prowadzić do absurdu. Tekst funkcjonuje bardziej jako opowiadanie, niż kodeks prawny. To, co słuchacz i czytelnik ma otrzymać, to nie zbiór niekompletnych i konkretnych przepisów postępowania, ale autentyczne i żywe odczucie tego, co słuszne i niesłuszne, odczucie ideału etycznego. Ideał znajduje się zawsze przed nami i jak gwiazda przewodnia wzywa do ciągłego postępowania naprzód.

2) Przykazanie miłości nieprzyjaciół. Dla etycznego nauczania Jezusa centralne znaczenie ma przykazanie miłości bliźniego. W 22, 40 przykazanie miłości Boga jawi się jako istota Prawa i Proroków. Przytaczane jest także w rozmowie z bogatym młodzieńcem $(19,19)$. To przykazanie zostało w omawianym tekście poszerzone i przedstawione jako niezbędny wymóg doskonałości. Powstaje pytanie, czy nie jest to jakaś niekonsekwencja, jeśli przykazanie miłości bliźniego jest modyfikowane i poszerzane (a nawet w 43b niejako relatywizowane), mimo że na innym miejscu ukazywane jest jako centrum i sama istota Prawa i Proroków? Otóż w rozumieniu Mateusza interpretacja przykazania miłości bliźniego jest właściwa wtedy, kiedy wyraźnie obejmuje także nieprzyjaciół, a zatem taka interpretacja, która nie uznaje żadnej granicy. Takie zachowanie charakteryzuje postawę Jezusa Chrystusa ujawnioną w całej Jego działalności zwłaszcza w męce i śmierci. Dlatego dążenie do doskonałości jest niczym innym jak pójściem za Jezusem. W Jezusie prześladowana wspólnota uczy się widzieć swych wrogów w nowym świetle i przezwyciężać swoje klanowe widzenie spraw.

3) Dwie uwagi praktyczne. Jezus nie wiązał miłości nieprzyjaciół z określonym celem do osiągnięcia. Miłość nieprzyjaciół nie ma być jakąś szansą dla wroga, aby stał się lepszym. Miłość w jakimś celu nie jest w ogóle miłością. Po wtóre, Jezus, także Mateusz i oczywiście wszyscy krytycy przykazania miłości nieprzyjaciół zgadzają się w tym, że to przykazanie nie jest wcale „naturalnym” wymogiem. Nie jest taktyką tego, kto walczy, nie jest wielkodusznością zwycięzcy, rezygnacją zwyciężonego ani dalekowzrocznością mędrca. Takie wymaganie Jezus postawił w oparciu o zupełnie „,nienaturalne" założenie bliskości Królestwa Bożego, wobec którego człowiek powinien dać odpowiedź. To wymaganie nie jest - jak nieraz wskazywano - szczytem „naturalnej” miłości człowieka. Mateusz przedstawia miłość nieprzyjaciół bynajmniej nie jako rozumną, naturalną, skuteczną, ale dlatego, że Ten, który je nadał, żyje w wspólnocie swych uczniów do skończenia świata jako zmartwychwstały Pan (Luz, I, 317).

4) Najwcześniejszym dziejom interpretacji tego fragmentu nieobce było przekonanie, że zawarte w Mt 5, 21-48 przykazanie miłości nieprzyjaciół jest do wykonania ${ }^{11}$. Przykładem jest wypowiedź w 2 Klem 13-14, gdzie 
czytamy, że każdy kto nienawidzi swego wroga, nie jest chrześcijaninem, ale czeka go sąd Boży. Z drugiej jednak strony tendencje łagodzące ostrość przykazania występowały bardzo wcześnie. Znamienny jest wspomniany wyżej 2 Klem 13n, gdzie chrześcijanie są napominani, że nie tylko nie miłują swych nieprzyjaciół, ale nawet nie miłują tych, którzy ich miłują. Widać z tego, że i z wewnątrzkościelną miłością nie było najlepiej. Pierwsza wyraźna modyfikacja pochodzi od Orygenesa, który zauważa, że polecenie „miłuj jak siebie samego" dotyczy wprost bliźniego, ale nie jest wyraźnie powiedziane, że dotyczy nieprzyjaciół. Wystarczy zatem, jeśli powstrzymamy się i ustrzeżemy się nienawiści w stosunku do nieprzyjaciół ${ }^{12}$.

Liczne były próby rozwiązania problemu przy pomocy dwustopniowej etyki. Ambroży np. stara się przypisać miłość nieprzyjaciół do tzw. doskonałych obowiązków i odróżnia ją od tzw. „zwyczajnych”13. Według Augustyna miłość nieprzyjaciół jest darem doskonałych dzieci Bożych, jakkolwiek każdy chrześcijanin powinien do takiej doskonałości dążyć. W średniowieczu i w scholastyce uważano, że wprawdzie nie można wykluczyć nieprzyjaciół z ogólnoludzkiej miłości, i każdy powinien być przygotowany do miłowania nieprzyjaciół, gdyby zaistniała taka konieczność. Jednakże poza taką koniecznością miłować nieprzyjaciela jest przejawem doskonałej miłości (pertinet ad perfectionem caritatis). Miłość nieprzyjaciół nie jest już ośrodkiem, ale miejscem granicznym praktyki chrześcijańskiej ${ }^{14}$.

Współcześnie najchętniej ogranicza się przykazanie do obszaru życia indywidualnego i osobistego. Idzie o przezwyciężenie osobistego uczucia nienawiści wobec wrogo usposobionego sąsiada, konkurenta itp. Punkt ciężkości przesuwa się z czynów miłości nieprzyjaciół w kierunku wewnętrznego nastawienia. Dla ewangelisty jednak miłość nieprzyjaciół oznacza jednak konkretny czyn.

Lublin

KS. ANTONI PACIOREK

${ }^{11}$ Chrystus nie podał nam niewykonalnych nakazów stwierdza np. Teodor z Heraklei, fr. $40=$ Reuss 68 .

${ }^{12}$ Hom in cant $2,8=$ PG 13,53 n.

${ }^{13}$ Off. 1,11 (37) = BKV 1/32. 28.

${ }^{14}$ Thomas, STh $2 /$ II qu 25 art. 8 n. 